\title{
SOCIO-ECONOMIC FEATURE STIRRING WOMEN PARTICIPATION IN LIVESTOCK ACTIVITIES
}

\author{
Tehmeena Ikram Ullah \\ Lecturer, Government Graduate College for Women, Samnabad Faisalabad \\ Farhana Nosheen \\ Assistant Professor, Department of Home Economics GC University Faisalabad \\ farhananosheen@gcuf.edu.pk
}

\author{
Fazeelat Naz \\ Government Special Education Center, Iqbal Town Faisalabad. \\ Department of Special Education Punjab, Pakistan \\ fazeelatnaz729@gmail.com
}

\section{ABSTRACT}

\begin{abstract}
Livestock is considered one of the major components in the farming system of Pakistan. Animals rearing, feeding, cutting fodder, cleaning shed and many other activities which are associated with livestock. Female contribution in livestock is remarkable and important in term of all above mentioned activities. The key objective of this study is to explore the women participation in this sector. For this study 400 respondents who belonged to three different geographical regions of Punjab (North, South and central) were taken to collect the information. Respondents were selected by using purposive sampling technique and tool of data collection was interview schedule. Statistical Package for Social Sciences was used to analyze the collected data. Data reveals the findings that more than half number of households (57.8\%) had 1-5 animals for rearing. Majority of the female performed livestock activities like poultry raising (54\%), raising of sheep (50\%), cutting fodder (36\%), cleaning of animals shed (31\%) and many other activities on daily basis. This percentage exposed the female contribution in this sector. There were negative repercussions on the health of women which indicated that almost (80\%) women suffered from different kind of diseases. The major findings of study reveal that in spite of huge contribution in livestock activities their participation is never acknowledge and appreciated. They are still impoverished in term of resources, incapacitated to take any decision and majority is illiterate to use new techniques in this sector which marginalized their economic benefits beside socio-cultural barriers. This study also propound that Government should initiate different programs and training to encourage people participation and mainly women to take part in these activities.
\end{abstract}

Keywords: Livestock, Activities, Animal, Rearing, Participation, Involvement, Raising, Female

\section{INTRODUCTION}

Women participation in livestock activities is phenomenal and remarkable around the globe but their contribution is not acknowledged by the society. Menhas et al., (2014) concluded that many women knew to get milk from animal and perform this task affectively in Halaba Special Woreda in Ethiopia and District Jhang respectively. It was witnessed that women from different regions involve in various activities like washing of ditch of feed in cattle and this was found to be the least among all the activities performed in relation to livestock management practices). A number of obstacles faced by women while performing livestock activities such as insufficient resources and technologies (Odoemelam et al., 2014)

Females from Pakistan participate actively and prominently in the sector of livestock. Plenty of time daily these women spend to do various kind of activities to look after the animals. These activities are consisted of cutting and preparing fodder, to arrange water for animals, to bring outside the animal for grazing. Cleaning their sheds, taking milk, and making dung cakes from their waste. Beside these activities they have responsibility to protect them from different kind diseases. Above all they take decision related to livestock management independently and in some situation with the help and support of males (Arshad et al., 2010). 
In the major milk producing areas Punjab and Sindh are considered main areas. The production of milk had been reached at 40 million MT in years 2006-07. Although Pakistan is stand on fifth number among largest milk producer countries yet the average yield per milk animal is not according to the capacity. It is low than the potential of milk production. A small quantity with 6 percent is processed hygienically and further used for milk products while a huge quantity of milk is used for domestic uses and sold by milkmen informally. The other treacherous practices like milk adulteration and unhygienic handling the milk pose serious outcome on health of people (USAID, 2009).

Afridi et al., (2009) concluded in their study and responded about the time spend by women in livestock activities. They spent five to six hours on daily basis to participate in animal's husbandry and animal rearing. Where $68 \%$ of above-mentioned time many rural women engaged in activities like milking, fodder cutting, collection of manure and animal feed and grazing. They explored that a woman from a household which possessed land in few acres spent their maximum time in cutting fodder (64.8 minutes) and shed cleaning and manure (43 minutes) while handling the animals. In view to analyze the percentage regarding participation in animal care and other related activities, the highest percentage $(98.76 \%$ ) was recorded in shed cleaning followed by farmyard manure collection $(87.34 \%)$, stall feeding $(87.05 \%)$, and watering/hauling $(85.78 \%)$.

There are many women who belong to impoverish families participate in financial matters to secure their families from hunger and starvation. So, it is evident from the findings of study that females from peasant families are significantly involved in livestock activities rather than females who belong to affluent families (Shafiq, 2008).

A study conducted in the rural areas of district Toba Tek Singh of Punjab and concluded by authors that women are more prudent and sensible as compared to male to look after the animals. The results of study explored those chances of occurrence disease among animals was less than men among animals cared by them and women earned more profit from livestock and animal rearing as compared to men. So, it was crux of research that livestock sector flourished positively and significantly due to the women involvement in this sector. It also helped to eradicate the poverty (Hashmi et al., 2007)

In Punjab, the activities like, fodder serving, serving water, dung collection, and milking are considered soft-natured activities and can be performed inside the four walls of home, so are mostly women's job. Activities like, fodder cutting, bathing the animals, milk selling are generally hardnatured and outside home activities, so are mostly performed by the men. Women's participation was low in the activities (like, milk selling) where more chances were there for them to interact with unknown males. So, cultural restriction of purdah (seclusion) and confined mobility were dynamic in Punjab. In rural Punjab, women were suffering from nutritional deficiency both in terms of quantity and quality. Fodder cutting, poultry raising, and milk processing are the activities largely done by women but despite spending much of their time for animal care and management their diet remained protein deficit, hence they remain malnourished (Saghir et al., 2005a).

The scientists and policymakers give very less attention and acknowledge the rural women participation in agriculture sector and animal husbandry in some agrarian countries around the globe (World Bank, 2009; FAO, 2012). Miscellaneous responsibilities related to animal rearing and management like fodder cutting, cleaning their sheds, collecting food, milking, preparing food and grazing, selling dairy products in market performed by women (Pakistan Agricultural Research Council, 2004; Saghir et al., 2005a)

Women work as an active agricultural workforce along with animals raring activities. It is evident that livestock work requires significant amount of time, hard work and specialized chores. Women are equally participating shoulder by shoulder with men in this sector. This huge proportion of women engaged in livestock activities is very valuable in terms of saving money. Otherwise, the same amount of time would be wasted in searching and hiring labor. Milk and milk products are advantageous in two ways. On one way people earn huge amount and generate income from dairy products and on other side they are used for domestic purpose. Women involvement in livestock really increases the workload for women as they must work at home as well as at farms. The studies conducted on time allocation found that the time spent by a woman on livestock chores ranges from 3 to 5 hours per day (Hamdani, 2002). 


\section{REVIEW OF LITERATURE}

Tahir Munir Butt et al., (2010) conducted the research in Okara district of Pakistan. The role of both rural male and female workers in agriculture was analyzed in the research. According to him, in spite of having strong potential to contribute to crop and livestock production and cottage industry, they had to face obstacles like insufficient access to resources, lack of knowledge regarding latest technology and innovation in agricultural sector. The rural women faced fundamental hurdles like cultural norms such as patriarchy and superstitious approach.

Arshad (2010) conducted research on topic "Role of Rural Women in Decision-Making Regarding Livestock Management. The research was conducted in Tehsil Jhang. The contribution of women in milk processing was almost 100 percent according to findings. Women had more contributions in other relevant activities of livestock like making and storage of dung cakes, collection of manures, caring of diseased animals, watering of animals, making feed concentrates and feeding of livestock, cleaning of animal sheds, fodder chopping and calf rearing. Their contribution was 90, 87.5, $82.5,77.5,75.8,72.5,68.3$ and 67.5 percent respectively.

According to Jamali's research (2009), women contribution in farm activities was not only confined to livestock. They also participated actively in livestock related activities like providing cattle for ploughing and harvesting. Women helped her family financially through this participation. Women performed extra chores in livestock to earn more money by trading in animals. They also manage poultry farm for more earning. Consequently, animals trading and poultry farming were major factors in women household income.

In 2009, Paudel stated that there is less involvement of women in publically launched livestock programs in Nepal. Towering disparity was found between men and women regarding the gender contribution in farmers' groups/organizations. Men's participation was found high in large animal, such as cattle and buffaloes' related groups, which are considered as the esteemed animals in the society, whereas women's contribution was confined to poultry farming groups only. Women were meant to work in most of the hard and cashless livestock activities, like forage collection and transportation, cleaning the gutter and sheds and feeding animals whereas men's involvement was more in the endorsed and (attractive) cashable livestock activities, like milking of the animals and selling of the milk. Involvement of women was found trivial in the decision-making process.

In the rural Punjab the research was conducted on the topic "Role of Livestock in Poverty Reduction" by Hashmi (2008). According to that research, the major contribution to livestock activities in Punjab was from women. Just milking and fodder chopping were done by men. All other work was done by female. Time spent on livestock activities by men is 2.83 hours per day, but women spent 4.71 hours a day. The reduction of poverty are the consequences of major contribution of women in livestock activities.

Okitoi et. al., (2007) declared that the involvement of the family members i.e women, men and children in poultry production system is common in Western Kenya. According to her study, the ownership of rural poultry shared among the family members was predominantly kept by the women (63\%) and children (18\%). All family members were giving services to poultry production, but women had to give more time and labor than that of men. Men and children had to construct poultry sheds while women did cleaning, feeding and treatment of rural poultry. Most of the daily routine poultry management chores were being performed by women and the children, whereas men were limited to the cash requiring occasional jobs such as purchase of inputs and treatment of poultry using relevant drugs. Women controlled the food and gifts to guests while men managed cash and cultural benefits springing from poultry. Decision-making by women in the rural poultry production system was limited to performing chores while cash related decisions were influenced by men.

Valdivia (2001) affirmed that in livestock economy, the allotment of labor is included in the resource management. There are gender differences in the management of livestock. There is important role of markets in the issuance of labor resources. She also declares that increasing the competition of female labor between the household activities, management of her own endeavors, household reproductive chores, working off farm activities, and others may increase the use of child labor as a strategy to address female's limitations. 


\section{RESEARCH METHODOLOGY}

The province of Punjab is divided geographically into three regions (Southern, Northern, Central). For current study three different areas from each geographical region respectively were selected to collect the data by using multistage sampling technique. At first stage three different districts (Multan, Chakwal, Chiniot) were taken randomly from each region. The main reason for the selection of three districts was to give the picture about female contribution in livestock activities of the whole Punjab and to increase the scope of the study from the viewpoint of generalization of the research findings, which are based on three geographical zones of the Punjab. After that three tehsil (Kalarkahar, Bhowana and Jalapur Pirwala) from each district was taken randomly. Afterwards one UC from kalarkahar, two UC from Bhowana and five from Jalalpur pirwala were again selected randomly. The selection of union councils varied due to number of rural populations of each tehsil. At next stage villages from each union council were selected randomly. At last, 25 females who were involved in farming system were selected from each village by using purposive sampling technique. Sample size was consisted of 400 respondents and instrument to get the information from respondents was wellstructured interview schedule to ask face to face questions. Data was analyzed by using software SPSS (Statistical Package for Social Sciences). Results of this study were drawn through the values of frequencies, percentage, mean and standard deviation.

\section{RESULT AND DISCUSSION}

This section provides the statistical information regarding under design study of women contribution in livestock management activities Punjab, Pakistan. Results are shown in the form of frequencies and percentages of data collected from respondents. This part of study makes it reliable and scientific.

\section{Table No. 1. Demographic Profile of Respondents}

\begin{tabular}{|l|l|l|l|l|l|}
\hline Category & \multicolumn{2}{l|}{ Responses } & Category & \multicolumn{2}{l|}{ Responses } \\
\hline Age (Years) & F & $\%$ & Education & F & $\%$ \\
\hline Up to 20 & 47 & 11.8 & Illiterate & 270 & 67.5 \\
\hline $21-30$ & 118 & 29.5 & Literate & 30 & 7.5 \\
\hline $31-40$ & 132 & 33 & Primary Pass & 52 & 13 \\
\hline 41 and Above & 103 & 25.7 & Middle Pass & 22 & 5.5 \\
\hline Total & 400 & 100 & Matric and Above & 26 & 6.5 \\
\hline $\begin{array}{l}\text { Income Household } \\
\text { (annual) }\end{array}$ & & & Total & 400 & 100 \\
\hline $80000-100000$ & 175 & 43.8 & Household Size & & \\
\hline $100001-120000$ & 106 & 26.5 & $1-5$ & 180 & 45 \\
\hline $120001-140000$ & 49 & 12.3 & $06-10$ & 207 & 51.7 \\
\hline $140001-160000$ & 32 & 8 & $11-15$ & 6 & 1.5 \\
\hline 160001 and Above & 38 & 9.5 & 16 and Above & 7 & 1.8 \\
\hline Total & 400 & 100 & Total & 400 & 100 \\
\hline
\end{tabular}

Table.1 depicts age structure of respondents. Age is important indicator to determine involvement in productive activates. This table presents $62.8 \%$ respondents were 21-40 years' old which show majority young women were involved in livestock activities only $11.8 \%$ female belonged to age of up to 20 years. They were highly active in Agriculture and livestock activities and performing different task. Majority of the respondent $67.5 \%$ were illiterate, $8 \%$ those who were literate, $13 \%$ had passed primary level exam while 5\% and 6\% respondents had passed middle and matriculation level of education respectively. Majority of respondents' household had annual income 80000-100000 (rupees), 26\% respondents' household annual income was 100001-120000, 12\% respondents' annual household income was 120001-140000 while 8\% and 10\% respondents had 140001-160000 and 160001 and above annual household income. It shows poor economic condition of rural area of Punjab. Majority of $45 \%$ respondents' household size consisted of 1-5 members and 52\% respondents with majority had 6-10 members in household while $1 \%$ and $2 \%$ respondents' household hold size were $11-15$ and 16 and above members. 
Table No. 2. Percentage distributions regarding Number of Animals reared by Household and Time management

\begin{tabular}{|l|l|l|l|}
\hline $\begin{array}{l}\text { Number of animals reared by household } \\
\text { (No.) }\end{array}$ & $\%$ & $\begin{array}{l}\text { Time Spend for Livestock } \\
\text { Activities(Hours) }\end{array}$ & $\%$ \\
\hline $1-5$ & 57.8 & $0-3$ & 31 \\
\hline $6-10$ & 20.8 & $4-7$ & 41 \\
\hline $11-15$ & 12.8 & $8-11$ & 19 \\
\hline $16-20$ & 6 & More than 12 & 09 \\
\hline $21-25$ & 2.3 & & \\
\hline 26 and Above & .5 & & \\
\hline Responses regarding management of domestic chores (\%) & Not at all \\
\hline Up to some extent & To great extent & 12 \\
\hline 54 & 34 &
\end{tabular}

Table 2 depicts the number of animals reared by household. Majority of (57.8\%) households had 1-5 animals cared by females and other family members which showed the economic condition of people in rural areas of Punjab. Only (.5\%) household possessed 26 and above number of animals. Further female responses about spending their time for animal husbandry. Majority (41\%) of respondents said they spent 4-6 hours on livestock management while only 9\% respondents spent more than 9 hours for animal care. Data Illustrated responses to manage domestic chores easily. Majority of female (54\%) managed easily their domestic chore to some extent while (34\%) could manage easily their household task to great extent and (12\%) were those females who could not manage their domestic chores.

Table No. 3. Percentage Distribution Livestock Activities

\begin{tabular}{|l|l|l|l|}
\hline Category & Level of Involvement \\
\hline Activities & Always (\%) & Rarely (\%) & Never (\%) \\
\hline Preparation of Fodder & 59 & 26 & 15 \\
\hline Milking & 40 & 23 & 37 \\
\hline Selling Milk and Milk Products & 55 & 12 & 27 \\
\hline Poultry Raising & 35 & 11 & 54 \\
\hline Egg selling & 39 & 26 & 45 \\
\hline Grazing of Sheep & 28 & 22 & 50 \\
\hline Collection of Animal feed & 47 & 22 & 31 \\
\hline Cleaning of Animal Sheds & 50 & 21 & 29 \\
\hline Making of Dung Cakes & 49 & 28 & 23 \\
\hline
\end{tabular}

Table.03 presents different livestock activities perform by women in rural area of Punjab. The activities in which female "always" participate were food preparation for animals (59\%), milking (40\%), selling of milk and milk products (55\%), collection of animal feed (47\%), cleaning of animals sheds $(50 \%)$ and making of dung cakes $(49 \%)$. There were certain livestock activities which were „never"e performed by female like poultry raising (54\%), egg selling (45\%), raising of sheep (50\%). These livestock activities were those in which women participation was less as compared to other activities.

Table 4 investigated women contribution in following household expenditures. Majority of women contributed always to this household expenditure like on food (41\%), clothes (37\%), Home maintenance $(32 \%)$, education (59\%), and health (49\%). While there were few women who did not contribute to household expenditure like food (23\%), clothes (25\%), home maintenance $(32 \%)$, education (20\%), health (16\%) recreation and festivals (40\%) and (38\%). presents health condition of respondents. Percentage distribution revealed the health impact of livestock on women health that majority $(80.5 \%)$ of respondents suffered from any diseases while only $(19.5 \%)$ did not suffer any kind of disease. 
Table No. 4. Percentage Distribution of Household Expenditure and Health Status

\begin{tabular}{|l|l|l|l|}
\hline \multirow{2}{*}{ Activities } & \multicolumn{3}{|c|}{ Level of Contribution } \\
\cline { 2 - 4 } & Always (\%) & Rarely (\%) & Never (\%) \\
\hline Food & 41 & 36 & 23 \\
\hline Cloth & 37 & 38 & 25 \\
\hline Home Maintenance & 32 & 36 & 32 \\
\hline Education & 59 & 21 & 20 \\
\hline Health & 49 & 35 & 16 \\
\hline Recreation & 21 & 39 & 40 \\
\hline Festival & 17 & 45 & 38 \\
\hline Suffering from any disease & \multicolumn{3}{|}{} \\
\hline Yes (\%) & \multicolumn{3}{|l|}{} \\
\hline 80.5 & No (\%) \\
\hline
\end{tabular}

\section{DISCUSSION}

The under-design study gives the picture of female participation in livestock in rural areas of Punjab, Pakistan. The results of study reveal that majority of women (62.8\%) were 21-40 years old which shows that majority were young. Population statistics of Pakistan also reveal that majority population is young and suitable for employment because age and employment have significant relationship. It was evident in research that women from rural areas of Pakistan did not enjoy healthy lives as they crossed their young age. They suffered from different type communicable and chronic diseases (Azid, et al 2001). So, this research also verified that there were very few women with the age of above 40 years who participated in livestock management on daily basis. Education is considered one of the important tools for the development and empowerment. Illiteracy is deep rooted in the rural areas of Pakistan and especially among females due to different socio-cultural factors. Majority of women $(67.5 \%)$ of the study were illiterate and never attended any school which shows vulnerability of rural women. Mahd (2014) conducted research on assessment of Women Farmers and their participation in agriculture extension services and related livestock activities and concluded that majority of female $85 \%$ were illiterate. Another study also reflected same condition of education among rural females. Dhillon et al (2007) stated that majority of female who worked on farms were illiterate. So, this phenomenon is also justified in this research that literacy rate in Pakistan is low and not satisfactory.

Poverty is fixed its claws in the root of Pakistan. A large portion of population lives below the poverty line. Pakistan with its fragile and deteriorating economic condition is unable to meet the need of common people. This study showed the economic condition of rural women through information regarding their annual income of the household. Majority of respondents (44\%) household had annual income 80000-100000 (rupees), 26\% respondents' household annual income was 100001-120000, $12 \%$ respondents' annual household income was 120001-140000 while 8\% and 10\% respondents had 140001-160000 and 160001 and above annual household income. It shows poor economic condition of rural area of Punjab. According to world bank definition of poverty a person who earn less than $\$ 1.25$ per day will be considered poor. In Economic Survey (2010-2011) of Pakistan shows earning of a person per month which was Rs.3243 rupees per month. Pakistan is ranked among the 43 countries most exposed to poverty risks which mean poverty trend is high. Thompson and Amjad (2008) stated that in Pakistan 20\% increase in food prices will result in $8 \%$ of poverty as a whole.

Pakistan is one of most populous country around the globe. It is one of fifth most populated country in world. Although different policies and programs were launched to control its population but still situation is complex and convoluted. The understudy research explored the household size of the respondents. $45 \%$ respondents' household size consisted of 1-5 members and 52\% respondents with majority had 6-10 members in household while $1 \%$ and $2 \%$ respondents' household hold size were 11-15 and 16 and above members. Zeba (2001) stated that Pakistan is transition phase in the context of demographic condition. But population growth rate is still high as compared to other developing countries. The total fertility rate (TFR) continued to remain high between six and seven births per woman throughout the 1970s and 1980s and the population growth rate approached and possibly exceeded three percent per annum. 
Livestock rearing is considered one of women job. It is evident in rural areas women look after the animals while men work on farms and other jobs. Almost every household had animals in rural locality of Punjab, Pakistan. It is considered one of the major sources of income and contribution in the household expenditure. Majority of (57.8\%) households had 1-5 animals cared by females and other family members which showed the economic condition of people in rural areas of Punjab. Only (.5\%) household possessed 26 and above number of animals. According to Livestock Census (2006) there are 29.56 million cattle, 27.33 million buffaloes, 26.49 million sheep and 53.79 million goats in Pakistan. Hence, livestock is occupying an important place in fulfilling the basic need of poor people and providing basic source of survival to the people of country (Tibbo, et al., 2009). In spite of this fact that livestock mainly depends on women, these women are spending their most of time on animal husbandry and care which increases household burden on them. Women spent significant time on animal husbandry and management beside their domestic chores. Majority of respondents faced difficulties to perform their domestic duties beside animal care. FAO (2012) stated that men are used to dealing with markets and women with domestic work but trends in Punjab are changing with its economy strengthening and changing independent due to their lead role in agriculture. Wage earning women bear a large burden of household chores

Women perform different duties to handle the animals. They performed different activities like cutting fodder, cleaning animal manure, grazing, and many others. This study also showed some livestock management activities performed by women in rural area of Punjab. The activities in which female ,always se participate were food preparation for animals (59\%), milking (40\%), selling of milk and milk products $(55 \%)$, collection of animal feed (47\%), cleaning of animals sheds $(50 \%)$ and making of dung cakes (49\%). Meinend Dick et al., (2004) stated that men and women have different right and duties to raring the animals may. Rights can be divided into rights to keep number of animals, access to resources including resource access, rights to selling the products, and right to take decisions such as management, exclusion, or alienation. Women fulfilled the need of milk consumption of household but cannot sell it for economic purpose.

It is obvious majority of household in the rural area meet their basic need through livestock not only use substances as a food item but also sell milk and products in market. It provides economic assistance to household. In this research women contribution in household expenditure were shown by asking them regarding different activities. Majority of women contributed always to this household expenditure like on food (41\%), clothes (37\%), Home maintenance (32\%), education (59\%), and health (49\%). The Himalayan Time (2006) reported that the participation of females in dairy farming had affected positively on the living standard of their family members. Further it stated that this activity contributes highly to the education of their children and also improve the health condition of their family members. This showed a significant contribution of women in home maintenance and other expenditure of household. It is also revealed by data that majority of women who looked after the animals suffered from different kind of diseases. This also exposed the health condition of women in rural areas of Punjab, Pakistan

\section{Bivariate Analysis}

Hypothesis 1: There is association between livestock management activities and contribution in household expenditure

Table No. 5. Association between Livestock Management Activities and Household Expenditure

\begin{tabular}{|l|l|r|r|r|r|}
\hline $\begin{array}{l}\text { Livestock } \\
\text { Activities }\end{array}$ & $\begin{array}{l}\text { Contribution } \\
\text { in household } \\
\text { Expenditure }\end{array}$ & Always & Rarely & Never & Total \\
\hline Always & & 42 & 104 & 8 & 154 \\
\hline Rarely & & 45 & 86 & 41 & 172 \\
\hline Never & & 18 & 35 & 21 & 74 \\
\hline Total & \multicolumn{7}{|c|}{105} & 225 & 70 & 400 \\
\hline Chi-square 28.176, sig:.000 Gama .222, sig: .002 \\
\hline
\end{tabular}

Table 5 represents the relationship between livestock activities and contribution in household expenditure. Chi-square value $(\chi 2=28.176)$ shows a highly significant $(\mathrm{p}=.000)$ association between livestock activities and household expenditure of the selected females. Gamma statistics in above 
table is indicating a strong positive and significant relationship between above discussed variables. It means women participation in animal care activities significantly contributed to family consumption expenditures. This automatically strengthens and improves the economic condition of households. So, the hypothesis "There is association between livestock management activities and contribution in household expenditure" is accepted.

Hypothesis 02: There is association between Livestock management activities and suffering from any kind of disease.

Table No. 6. Livestock Management Activities and kinds of Diseases

\begin{tabular}{|l|l|l|l|r|}
\hline $\begin{array}{l}\text { Livestock } \\
\text { Activities }\end{array}$ & $\begin{array}{l}\text { Suffering from } \\
\text { any kind of } \\
\text { diseases }\end{array}$ & Yes & No & Total \\
\hline Always & & 141 & 13 & 154 \\
\hline Rarely & & 136 & 36 & 74 \\
\hline Never & & 45 & 29 & 400 \\
\hline Total & 105 & 225 & \\
\hline \multicolumn{2}{|l|}{ Chi-square 30.49, sig:.000 Gama .535, sig: .000 } \\
\hline
\end{tabular}

Table 6 depicts the impacts of livestock management and health status of selected females. Chi-square value $(\chi 2=30.49)$ shows a highly significant $(p=.000)$ association between participation in livestock activities of the selected females and their health status. Gamma statistics indicating a strong positive and significant relationship between above discussed variables. It indicates that majority of women were suffering from different kind of diseases while there were few in numbers who were healthy and did not have any kind of health issues. So, the hypothesis "There is association between selected females' contribution in living stock activities and suffering from any kind of diseases impacts on health" is accepted.

Hypothesis 3: There is association between livestock activities and management of domestic chores.

Table No. 7. Livestock Activities and Management of Domestic Chores

\begin{tabular}{|c|c|c|c|c|c|}
\hline $\begin{array}{l}\text { Livestock } \\
\text { Activities }\end{array}$ & $\begin{array}{l}\text { Domestic } \\
\text { chores } \\
\text { management }\end{array}$ & $\begin{array}{l}\text { To Some } \\
\text { Extent }\end{array}$ & $\begin{array}{l}\text { To Great } \\
\text { Extent }\end{array}$ & Not at All & Total \\
\hline Always & & 87 & 57 & 10 & 154 \\
\hline Rarely & & 100 & 65 & 7 & 172 \\
\hline Never & & 30 & 15 & 29 & 74 \\
\hline Total & & 217 & 137 & 46 & 400 \\
\hline
\end{tabular}

Table 6 reveals the association and relationship between participation in livestock management and performing domestic chores by selected females. Chi-square value $(\chi 2=69.33)$ shows a highly significant $(\mathrm{p}=.000)$ association between age of the selected females and their living style. Gamma statistics indicates a strong positive and significant relationship between above discussed variables. It presents that majority of females who performed livestock activities in addition to domestic chores did not easily manage their work. They put additional charge on their shoulders which further lead to role strains and many other issues. Statistics shows, there were majority of women respond that to some extent they managed their work easily. There was little number of females who did not feel burden to perform livestock activities beside domestic chores. So, the hypothesis "There is association between livestock activities and management of domestic chores" is accepted

\section{CONCLUSION}

The study concluded that women are actively participated in different activities of livestock management. Women performed livestock activities beside domestic chores which burdened the women more as compared to men. They spend plenty of time on daily basis in different task related to animal care like cutting and preparing food, grazing, cleaning sheds and manure, milking and selling of milk and making dung cakes, watering of animals and many others. Beside this poultry raising and egg selling is also considered duty of women. It is obvious that livestock is one sector in which women involvement is significant and admirable. Majority of household in rural areas meet their basic 
need from this sector by using and selling products and meet of animals. Beside this positive impact livestock management has some negative repercussion on the health of women which revealed the health status of rural women also. So, it is evident from study that women contribution should be acknowledge and appreciable around the globe and especially in Pakistan. It is blessing for a country like a Pakistan that its climate is suitable for animal rearing so women contribution must be increased by providing facilities and financial assistance to get more befit from it.

\section{REFERENCES}

Ahmad, T. I. (2014). The role of rural women in livestock management: socio-economic evidences from diverse geographical locations of Punjab (Pakistan). MSc Thesis, University of Toulouse le Mirail.

Arshad, S. S., Muhammad, M. A., Randhawa, I., \& Choudhry, K. M. (2010). Rural women's involvement in decision-making regarding livestock management. Pakistan J. Agri. Sci, 47(2), 1-4.

Afridi, G. S., Ishaq, M., \& Ahmad. S. (2009). Estimation of Costs and Returns and Factor Productivity in Livestock Enterprise in Northern Areas, Pakistan. Pakistan Journal of Life and Social Sciences, 7(1), 43-51.

Azid, T., Aslam, M., \& Chaudhary, M. O. (2001). Poverty, Female Labour Force Participation, and Cottage Industry: A Case Study of Cloth Embroidery in Rural Multan". The Pakistan Development Review, 40(4), 1105-1118.

Dhillon, M. K. (2007). Involvement of farm women in agricultural and allied activities-factors associated and constraints faced. Indian J. Soc, 48, 221-227.

FAO, (2012). Women Manage Livestock Diversity. FAO Rome

Hashmi, A. (2008). Socio-economic analysis of livestock towards poverty alleviation and gender participation in livestock management in rural areas of the Punjab.

Hashmi, A. H., Maann, A. A., Asghar, K., \& Riaz, M. (2007). Gender Role in Livestock Management and their Implication for Poverty Reduction in Rural Toba Tek Singh, Punjab. Pakistan Journal of Agricultural Sciences, 44(4)-674-678.

Hamdani, L. A. S. (2002). Role of Rural Women in Poverty Alleviation through Keeping of Livestock". Participant of 82nd Advance Course in Public Sector Management, National Institute of Public Administration (NIPA), Lahore, Pakistan.

Jamali, K. (2009). The role of rural women in agriculture and it"s allied fields: A case study of Pakistan. Europ. J. Social Sci, 7(3) ,74-75.

Menhas, R., Yaqoob, M., Akhtar, S. \& Jabeen, N. (2014). Gender Empowerment Through Livestock Care and Management: A Case Study of District Jhang. Innovare J. Soc, 2 (2), 35-37.

Mahd. (2014). An Assessment of Women Farmers' Participation in Agricultural Extension Services for Income and Nutrition Improvement in Ethiopia: The Case of Becho District, South West Oromia.

Meinzen-Dick, R., Pradhan, R., \& di Gregorio, M. (2004). Collective Action and Property Rights for Sustainable Development: Understanding Property Rights, 2020 Focus Brief 11. International Food Policy Research Institute, Washington, D.C.

Odoemelam, L. E., Alamba, C., \& Lekan-Akomolate, C. N. (2014). Evaluation of Women Access and Rights to Land and Its Implications on Rural Household Food Security in Selected Rural Communities, Abia State, Nigeria.

Okitoi, L. O., Ondwasy, H. O., M. P. Obali, M. P., \& Murekefu, F. (2007). Gender issues in poultry production in rural households of Western Kenya. Livestock Research for Rural Development, $19(2)$.

Paudel, L. N., Meulen, U., Wollny, C., Dahal, H., \& Gauly, M. (2009). Gender Aspects in Livestock Farming: Pertinent Issues for Sustainable Livestock Development in Nepal. Livestock Research for Rural Development. 21(3).

S. Mthi et al. (2018). Women's participation in livestock activities under small-scale farming system in the Eastern Cape Province, South Africa. Applied Animal Husbandry \& Rural Development, 11(1),14-21. 
Saghir, A., Ali, T., Ahmad, M., \& Zakaria, M. (2005). Gender Participation in Livestock Production Activities and their Consumption Trends of Proteineous Diet in Tehsil Fateh Jung" Pakistan. Journal of Agricultural Sciences, 42(3-4), 89-92.

Shafiq, M., (2008). Analysis of the role of women in livestock production in Balochistan", Pakistan. Journal of Agricultural and Social Sciences, 4(1),18-22.

Butt et al. (2010). Role of Rural Women in Agricultural Development and Their Constraints. J. Agric. Soc. Sci., 6(3), 53-56.

Tibbo, M., Abdelali-Martini, M., Tariq, B., Salehy, P., Khan, M. A., Anwar, M. A., Manan, A. R., Rischkowsky, B., \& Aw-Hassan, B. (2009). Conservative Societies: the Case of Women Livelihoods and Dairy Goat Programme in Afghanistan and Pakistan" paper presented at the FAO-IFADILO Workshop on Gaps, trends and current research in gender dimensions of agricultural and rural employment: differentiated pathways out of poverty. Rome, 31 March 2 April 2009.

The Himalayan times. (2006). Women do 70 pc of work in dairy farming: Survey. May 11. $\mathrm{http} / / /$ thehimalayantimes.com/kathmandu/women-do-70-pc-of-work-i n-dairy-farming-survey

USAID. (2009). Promoting Gender Equitable Opportunities: Why it Matters for Agricultural Value Chains. US Agency for International Development

Valdivia, C. (2001). Gender, livestock assets, resource management, and food security: Lessons from the SR-CRSP”, Agriculture and Human, 18(1), 27-29.

World Bank. (2009). Gender in agriculture source book. World Bank Washington D.C

Zeba, S. A. (2001). The much-awaited fertility decline in Pakistan: Wishful thinking or reality?' Int. Family Planning Pers. 19, 142-146 